\title{
ADEQUAÇÃO DE NUTRIENTES DO MEIO MT PARA O CULTIVO DE EMBRIÕES IMATUROS DE TANGERINEIRA 'CLEÓPATRA’’
}

\author{
LUCYMEIRE SOUZA MORAIS-LINO², ANTÔNIO DA SILVA SOUZA ${ }^{3}$, WALTER DOS SANTOS SOARES FILHO², \\ CARLOS ALBERTODA SILVALEDO ${ }^{3}$
}

RESUMO - Este trabalho teve como objetivo ajustar a concentração de macronutrientes, micronutrientes e vitaminas do meio de cultura Murashige \& Tucker (MT), de modo a permitir a germinação de embriões imaturos, menores que $3 \mathrm{~mm}$, de tangerineira 'Cleópatra'. As sementes foram obtidas a partir de frutos com 4 a 5 meses após a antese, cujos embriões não germinam nos meios de cultura atualmente indicados para citros. Inicialmente, os embriões foram cultivados em meio de cultura básico contendo sacarose e ágar, seguindo uma seqüência de etapas, procedendo-se a ajustes da concentração normal dos macronutrientes $(1 / 1,1 / 2 \mathrm{e} 1 / 4)$, micronutrientes $(1 / 1,1 / 2,1 / 4$ e $1 / 1,3 / 2,2 / 1)$ e vitaminas $(2 / 1,1 / 1$ e $1 / 2)$ do meio MT. O delineamento experimental foi inteiramente casualizado, em um esquema fatorial 3 (concentrações do MT) x 4 (comprimentos de embriões), com 10 repetições. As variáveis, porcentagem de germinação de embriões, porcentagem de plântulas normais e comprimentos dessas plântulas foram avaliadas 30 dias após a inoculação dos embriões em meio de cultura. Os melhores resultados foram obtidos utilizando-se de metade da concentração normal de macronutrientes, não havendo necessidade de alterar as concentrações de micronutrientes e vitaminas.

Termos para indexação: Citrus reshni Hort ex Tan., resgate de embriões, cultura de tecidos.

\section{ADJUSTMENT OF NUTRIENTS OF THE MT MEDIUM FOR THE CULTIVATION OF 'CLEÓPATRA' TANGERINE IMMATURE EMBRYOS}

\begin{abstract}
The objective of the present work was to adjust the macronutrient, micronutrient and vitamin concentrations of the Murashige \& Tucker (MT) culture medium in order to promote the germination of 'Cleopatra' Tangerine immature embryos, smaller than $3 \mathrm{~mm}$. Seeds from fruits, 4 to 5 months after anthesis, in which the embryos do not germinate in recently indicated culture media for citrus, were used. Initially, the embryos were cultivated in basic culture medium containing sucrose and agar, followed by a sequence of steps, carrying out the adjustments of the normal concentration of macronutrients $(1 / 1,1 / 2$ and $1 / 4)$, micronutrients $(1 / 1,1 / 2$, $1 / 4$ and $1 / 1,3 / 2,2 / 1)$ and vitamins $\left(2 / 1,1 / 1 \mathrm{e}^{1 / 2}\right)$ of the MT medium. The experimental design was completely randomized in factorial scheme 3 (concentrations of MT) x 4 (embryo size), with 10 repetitions. The following variables were evaluated thirty days after embryo inoculation in culture medium: percentage of germination, percentage of normal plantlets and plantlet length. The best results were obtained using half the normal concentration of macronutrients, whereas the concentrations of micronutrients and vitamins remained unaltered.
\end{abstract}

Index terms: Citrus reshni hort. ex Tanaka, embryo rescue, tissue culture.

\section{INTRODUÇÃO}

O Citrus e gêneros afins reúnem uma imensa variabilidade genética, passível de ser explorada em hibridações visando ao desenvolvimento de novas variedades. Entretanto, o melhoramento genético dos citros por meio dos métodos convencionais apresenta um sério obstáculo, que é a presença da poliembrionia das sementes da maioria das espécies e variedades. Em citros poliembriônicos, o embrião zigótico tem de competir por nutrientes e espaço com embriões desenvolvidos a partir do nucelo (Soost \& Roose, 1996). A presença desses embriões tem possibilitado a perpetuação natural de características varietais desejáveis (Hanna \& Bashaw, 1987), mas prejudica a germinação dos embriões zigóticos e a distinção precoce das plântulas híbridas dos nucelares (Koller, 1994; Domingues et al., 1998). Conseqüentemente, a demanda por métodos para separar os embriões zigóticos dos nucelares tem aumentado (Bastianel et al., 1998).

Diversos estudos têm sido realizados no sentido de ampliar as possibilidades de identificação de genótipos de origem sexuada (zigóticos) provenientes de sementes poliembriônicas de citros, tanto em nível de embrião como de plântulas jovens. As diversas técnicas geradas para a identificação do embrião sexual, como o uso de marcadores isoenzimáticos (Medeiros et al., 2000) e RAPD (Andrade-Rodríguez et al., 2005), entretanto, são muitas vezes inviáveis sob o ponto de vista econômico. Assim sendo, a eliminação ou redução da manifestação da poliembrionia torna-se importante, podendo ser viabilizada pelo cultivo in vitro dos primeiros embriões que se formam em sementes poliembriônicas, com base na pressuposição de que estes possuem grande possibilidade de serem zigóticos, conforme sugerido por Vásquez Araújo (1991). Assim, é necessário resgatar

'(Trabalho 077-07). Recebido em: 23-03-2007. Aceito para publicação em: 03-11-2007. Parte da dissertação apresentada pelo primeiro autor para obtenção do grau de mestre em Ciências Agrárias, Universidade Federal da Bahia (UFBA).

${ }^{2}$ Doutoranda do Curso de Pós-Graduação em Biotecnologia da UEFS, Br 116, km 03, CEP 44031-460, Feira de Santana-BA. E-mail: 1smorais@yahoo.com.br. ${ }^{3}$ Pesquisadores da Embrapa Mandioca e Fruticultura Tropical, Caixa Postal 007, CEP 44.380-000, Cruz das Almas-BA. E-mail: assouza@cnpmf.embrapa.br; wsoares@cnpmf.embrapa.br; ledo@cnpmf.embrapa.br. 
embriões na fase imatura para reduzir o risco de aborto e competição com os embriões nucelares (Viloria et al., 2005). O cultivo in vitro de embriões imaturos é limitado nos meios de cultura atualmente indicados para variedades cítricas, dentre os quais o MT (Murashige \& Tucker, 1969), que se destaca como o mais utilizado.

Deve-se considerar, porém, a necessidade de ajustes nos meios de cultivo in vitro atualmente disponíveis para embriões de citros, a exemplo do MS (Murashige \& Skoog, 1962) e MT, em razão de sua baixa eficiência para a germinação e desenvolvimento de embriões imaturos (Vásquez Araújo, 1991). Segundo Krikorian (1991), o meio MS, que é semelhante ao MT, possui um alto conteúdo de sais, influenciando negativamente no desenvolvimento normal dos embriões. De acordo com George (1993), o mais importante em cultura de tecidos de plantas é selecionar macronutrientes, micronutrientes e vitaminas segundo uma concentração e balanço corretos, definindo-se, por exemplo, o meio de cultura que possa permitir o crescimento e o desenvolvimento in vitro de embriões imaturos $(\mathrm{Hu} \&$ Ferreira, 1998).

Este trabalho teve como objetivo ajustar a concentração dos sais minerais e vitaminas do meio MT, de modo a permitir a germinação de embriões imaturos (menores que $3 \mathrm{~mm}$ ), tanto nucelares quanto zigóticos, de tangerineira 'Cleópatra' (Citrus reshni hort. ex Tanaka).

\section{MATERIAL E MÉTODOS}

O trabalho foi conduzido na Embrapa Mandioca $\boldsymbol{e}$ Fruticultura Tropical. Plantas de tangerineira 'Cleópatra' (Citrus reshni hort. ex Tanaka), pertencentes ao Banco Ativo de Germoplasma (BAG) de citros, foram selecionadas em virtude do alto grau de poliembrionia dessa variedade. Os botões florais (em formato de balão) foram devidamente identificados, e os frutos foram coletados após um período de 4 e 8 meses

Os frutos, após a colheita, foram transportados para o Laboratório de Cultura de Tecidos, lavados em água corrente, sendo suas sementes removidas mediante corte transversal incompleto, garantindo assim a integridade das mesmas. $\mathrm{O}$ tegumento externo, testa de sementes provenientes de frutos com 8 meses de idade, foi retirado. Para os frutos com 4 a 5 meses após a antese, não foi necessário realizar o mesmo procedimento. Sob condições assépticas, em câmara de fluxo laminar estéril, as sementes foram tratadas com uma solução de etanol $70 \%$, por 5 minutos, e, posteriormente, com hipoclorito de cálcio a $0,25 \%$, durante 20 minutos. Após cada período de tratamento, foi efetuada a tríplice lavagem com água destilada autoclavada.

Com auxílio de um bisturi, os embriões foram excisados sob microscópio estereoscópio, sendo agrupados em quatro classes distintas de comprimento, a saber: $<1,0 \mathrm{~mm}, 1,0$ a $1,9 \mathrm{~mm}$, 2,0 a $2,9 \mathrm{~mm}$ e $>6,0 \mathrm{~mm}$, esta última utilizada como testemunha. As medidas $(\mu \mathrm{m})$ foram tomadas com o auxílio de uma lente micrométrica graduada conectada na ocular do microscópio estereoscópio, considerando as dimensões do embrião, incluindo os cotilédones. As mensurações foram corrigidas, utilizando-se de um fator de correção $(\mathrm{x}=0,157)$.
Os embriões foram cultivados em tubos de ensaio $(25 \mathrm{x}$ $150 \mathrm{~mm}$ ) com $10 \mathrm{~mL}$ de meio de cultura, contendo, como compostos básicos, $30 \mathrm{~g} \mathrm{~L}^{-1}$ de sacarose e $7 \mathrm{~g} \mathrm{~L}^{-1}$ de ágar, observando uma seqüência de etapas ao longo das quais se procedeu ao acréscimo, acompanhado dos respectivos ajustes, de macronutrientes, micronutrientes e vitaminas. Foram avaliadas as seguintes concentrações: $1 / 1$ (concentração normal do meio de cultura MT), 1/2 (metade da concentração normal do MT) e 1/4 (quarta parte da concentração normal do MT), para macronutrientes e Etapa I dos micronutrientes; 1/1, 3/2 (uma vez e meia a concentração normal do MT) e 2/1 (dobro da concentração normal do meio de cultura MT) para a Etapa II de micronutrientes; $2 / 1,1 / 1$ e $1 / 2$ para vitaminas. Os embriões foram cultivados em sala de crescimento, com temperatura de $27 \pm 2^{\circ} \mathrm{C}$, fotoperíodo de 16 horas e intensidade luminosa de $50 \mathrm{mmol} \cdot \mathrm{m}^{2} . \mathrm{s}^{-1}$, fornecidas por lâmpadas fluorescentes brancas frias.

Em cada experimento, usou-se o melhor resultado do experimento anterior, seguindo-se a seqüência das etapas de ajustes dos constituintes.

O delineamento foi inteiramente casualizado, em esquema fatorial $3 \times 4$, três concentrações do meio MT $(1 / 1,1 / 2$ e $1 / 4$ ou $1 / 1$, $3 / 2$ e $2 / 1$ ou $2 / 1,1 / 1$ e $1 / 2$ ), quatro classes de comprimento de embriões $(<1,0 \mathrm{~mm}, 1,0$ a $1,9 \mathrm{~mm}, 2,0$ a $2,9 \mathrm{~mm}$ e a testemunha $>6,0$ $\mathrm{mm})$, com dez repetições, sendo cada repetição constituída por um embrião. Após trinta dias de cultivo dos embriões, foram realizadas as seguintes avaliações: comprimento de plântulas, porcentagem de germinação e de plântulas normais. Para a variável comprimento de plântulas, realizaram-se a análise de variância e o teste de Tukey, a 5\% de probabilidade, para a comparação das médias. As porcentagens de germinação e de plântulas normais (plântulas que apresentaram desenvolvimento de raiz e parte área) foram obtidas a partir das médias das dez repetições de cada tratamento, ou seja, cada tratamento é representado por apenas um valor.

\section{RESULTADOS E DISCUSSÃO}

\section{Ajuste de macronutrientes}

Foi observado $100 \%$ de germinação de embriões para a maioria dos tratamentos, à exceção dos embriões cultivados no meio com a concentração normal dos macronutrientes e com comprimentos inferiores a 2,0 $\mathrm{mm}$, que apresentaram, em média, $93 \%$ de germinação para os embriões menores que $1,0 \mathrm{~mm}$ e para embriões com comprimento entre 1,0 e 1,9 mm (dados nãomostrados). As plântulas resultantes dos embriões de menor comprimento apresentaram-se pouco desenvolvidas (Figura 1), especialmente aquelas cultivadas no meio de cultura com concentração normal de macronutrientes do MT, com $80 \%$ das plântulas fora do padrão normal (Figura 2). Segundo Krikorian (1991), a presença de alto conteúdo de sais no meio de cultura, como acontece no MT, é inadequada ao processo morfogenético (Pasqual et al., 2002), interferindo, portanto, no desenvolvimento normal das plântulas.

O mais importante em cultura de tecidos de plantas é selecionar macro e micronutrientes segundo concentração e balanço corretos. George (1993) observou que a embriogênese 
poderia ser induzida mais efetivamente em calos derivados de anteras de Hevea brasiliensis Muell Arg., reduzindo-se o nível de macronutrientes do meio MS, que é semelhante ao MT, para 60-80\%. Ribeiro (1997), cultivando embriões zigóticos e nucelares oriundos de hibridações controladas entre a laranjeira 'Natal' [ $C$. sinensis (L.) Osb.] e Poncirus trifoliata (L.) Raf., alterou as porcentagens dos sais do MS, obtendo bom desenvolvimento e crescimento dos mesmos em meio com $75 \%$ da concentração original de sais.

Considerando-se apenas os embriões de comprimento inferior a 1,0 mm, verificou-se que o emprego de metade da concentração normal de macronutrientes do meio MT proporcionou o desenvolvimento de plântulas com maior comprimento $(20,1 \mathrm{~mm})$ (Figura 1) e a maior freqüência de plântulas normais (90\%) (Figura 2).

\section{Ajuste de micronutrientes}

Os ajustes de micronutrientes foram realizados em duas etapas, em concentrações inferiores (Etapa I) e superiores (Etapa II) à concentração normal do meio MT.

A porcentagem de germinação dos embriões, independentemente da concentração de micronutrientes, foi de $100 \%$ (dados não-mostrados).

Para o carácter de plântulas normais (Figura 3), verificouse também que os ajustes de micronutrientes (Etapas I) não diferiram entre si, independentemente do comprimento do embrião, apresentando altas taxas de plântulas normais, $100 \%$ para as concentrações normais (1/1) e (1/4) e $92,5 \%$ para a metade da concentração de micronutrientes. Na Etapa II, observou-se que houve diferenças significativas entre os tratamentos e os comprimentos de embriões. Maior freqüência de plântulas normais foram obtidas a partir de embriões de menor comprimento, quando comparadas aos demais comprimentos de embriões, cultivados em meio de cultura com concentração normal de micronutrientes do MT.

Quanto ao comprimento de plântulas (Figura 4), a diminuição da concentração normal (Etapa I) determinou, em geral, comportamentos semelhantes, à exceção dos embriões de comprimento inferior a 1,0 mm, para os quais as concentrações mais adequadas foram a normal (1/1) e quarta parte da normal (1/4). Quanto ao aumento da concentração normal (Etapa II), só se mostrou significativo com os embriões de comprimento inferior a 1,0 mm, destacando-se as concentrações normais (1/1) e o dobro desta. Esses resultados demonstram ampla faixa de resposta dos embriões de menor comprimento às diferentes concentrações de micronutrientes.

O crescimento de células e a morfogênese de algumas espécies podem ser obtidos com sucesso elevando-se o nível de micronutrientes. George (1993) observou melhor resposta embriogênica em calos originados de anteras de Hevea brasiliensis dobrando-se a concentração original de micronutrientes. Observa-se, portanto, que, para cada cultura e tipo de explante, podem ser obtidos resultados distintos, dependendo da concentração de micronutrientes utilizada.

Passos et al. (1992) reduziram para metade a concentração de sais totais do MS e obtiveram sucesso no resgate de embriões de videira. Ribeiro et al. (1998), estudando o cultivo in vitro de embriões de laranjeira 'Pêra' [Citrus sinensis (L.) Osbeck], observaram que a concentração de $75 \%$ do meio de cultura de MS foi a mais responsiva para quase todas as variáveis avaliadas, indicando que os componentes da fórmula original do meio encontram-se acima do requerido para o melhor desenvolvimento e crescimento in vitro dos embriões dessa espécie. Pasqual et al. (2002), estudando diferentes concentrações dos sais do MS no cultivo in vitro de embriões imaturos de tangerineira 'Poncã' $(C$. reticulata Blanco), observaram que o melhor resultado foi obtido com a concentração original do meio MS. Por sua vez, Chagas et al. (2003a) obtiveram o melhor desenvolvimento de embriões imaturos de 'Pêra-Rio' $x$ 'Poncã', no estádio cotiledonar, em meio de cultura contendo a concentração de $150 \%$ do meio MT, sendo que o melhor desenvolvimento desses embriões, no estádio globular, ocorreu com 50\% e 100\% do meio MT (Chagas et al., 2003b). Como pode ser visto, os trabalhos relacionados com a germinação de embriões imaturos utilizam reduções do meio de cultura total, ou seja, associando macronutrientes, micronutrientes e vitaminas, diferentemente do presente estudo, que testou cada conjunto de nutrientes e vitaminas separadamente.

Assim, para as variáveis estudadas, de modo geral, a concentração normal de micronutrientes do meio MT não exige a realização de ajustes visando a favorecer a germinação dos embriões, o crescimento e o desenvolvimento de plântulas normais oriundas de embriões imaturos de tangerineira 'Cleópatra'.

\section{Ajuste de vitaminas}

Os ajustes nas concentrações de vitaminas foram realizados com base no meio de cultura definido a partir dos dados do ajuste de micronutrientes. A porcentagem de germinação de embriões, independentemente da concentração de vitaminas, foi de $100 \%$ (dados não- mostrados), entre os comprimentos de embriões e as concentrações de vitaminas utilizadas, todas manifestando resultados plenamente favoráveis (100\% de germinação). As variáveis comprimento de plântulas (Figura 5) e porcentagem de plântulas normais (Figura 6) apresentaram resultados ligeiramente superiores na concentração normal de vitaminas do MT (1/1), independentemente do comprimento dos embriões. Esses resultados diferem dos obtidos por Chagas et al. (2003b) que, avaliando diferentes concentrações de vitaminas do meio MT no desenvolvimento de embriões globulares de citros, observaram que as vitaminas do meio de cultura MT não indicaram ser essencial para o cultivo in vitro de embriões globulares da hibridação entre 'Pêra-Rio' e 'Poncã'.

O requerimento das células por vitaminas varia de acordo com o genótipo da planta e o tipo de cultura (George, 1993). No caso dos citros, níveis ótimos de algumas vitaminas para cultivo de tecidos foram estabelecidos por Murashige \& Tucker (1969). No entanto, o fator genótipo deve ser considerado, verificando a necessidade de aumentar ou diminuir a concentração das vitaminas (Huang et al., 1985) e, às vezes, outras vitaminas devem ser acrescentadas à mistura-padrão.

De acordo com os resultados obtidos, observou-se que, 
para o desenvolvimento de plântulas normais de tangerineira 'Cleópatra' oriundas de embriões imaturos, não foi necessário proceder-se a ajustes no teor de vitaminas.

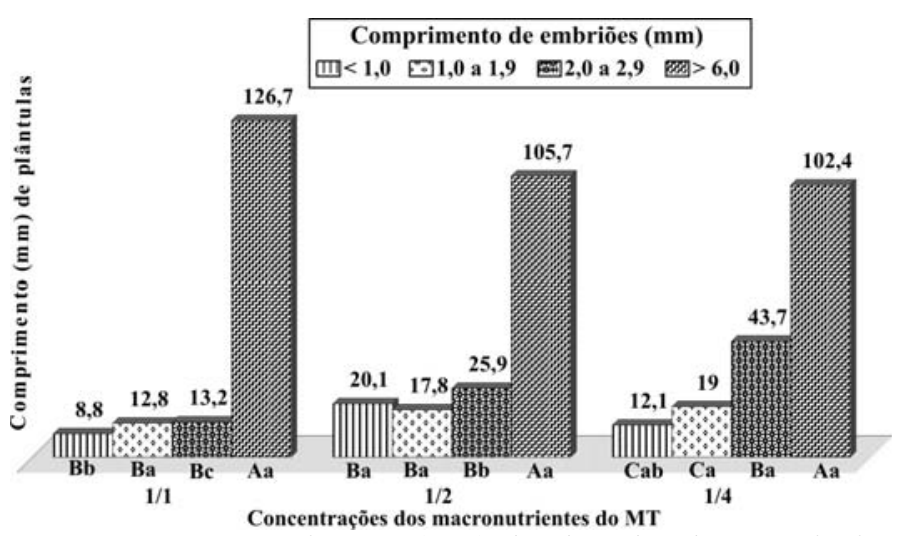

FIGURA 1 - Comprimento $(\mathrm{mm})$ de plântulas de tangerineira 'Cleópatra' (C. reshni Hort ex Tan.), em função do comprimento do embrião e do cultivo por trinta dias em diferentes concentrações de macronutrientes do meio MT. Médias seguidas da mesma letra maiúscula dentro de cada concentração e da mesma letra minúscula entre cada classe de comprimento dentro das concentrações não diferem estatisticamente, ao nível de 5\% de probabilidade, pelo teste de Tukey.

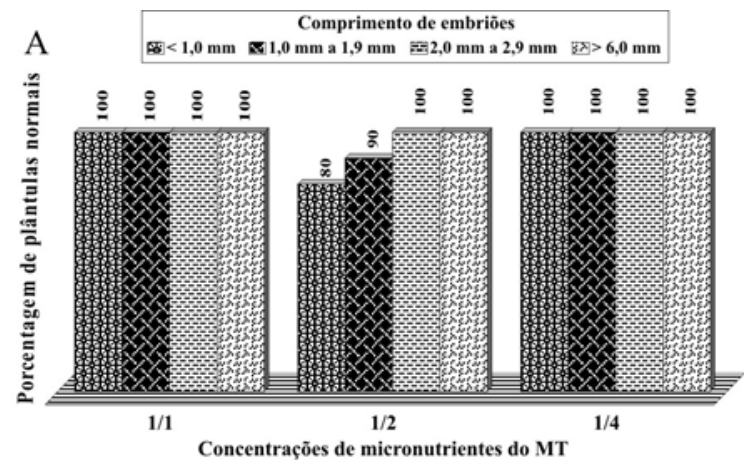

Essas modificações no meio MT são direcionadas somente ao uso de frutos com 4 a 5 meses de tangerineira 'Cleópatra' após a antese, que possuem embriões imaturos de comprimento pequeno $(<3,0 \mathrm{~mm})$.

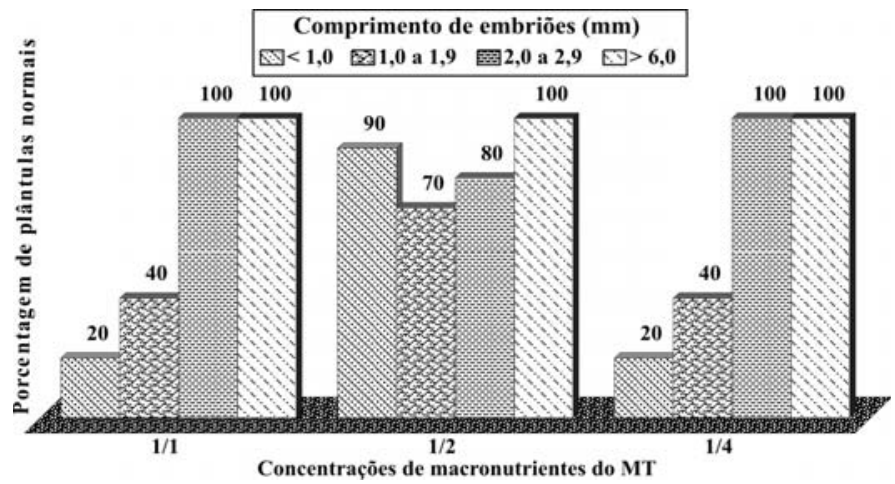

FIGURA 2 - Porcentagem de plântulas normais de tangerineira 'Cleópatra' (C. reshni Hort ex Tan.), cultivadas durante trinta dias em diferentes concentrações de macronutrientes do meio MT, em função do comprimento de embrião

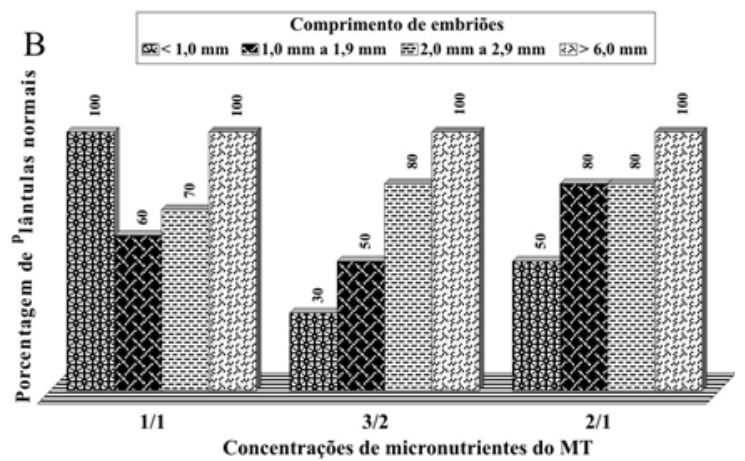

FIGURA 3 - Porcentagem de plântulas normais de tangerineira 'Cleópatra' (C. reshni Hort. ex Tan.), em função do comprimento do embrião e do cultivo em diferentes concentrações de micronutrientes do meio MT (A: Etapa I e B: Etapa II).
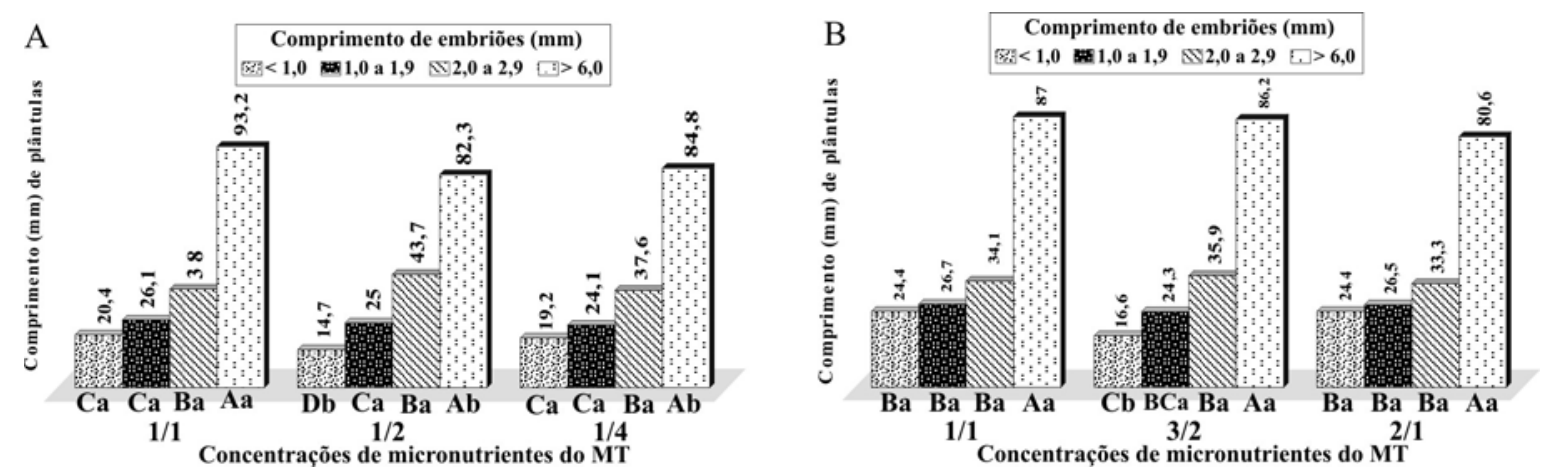

FIGURA 4 - Comprimento (mm) de plântulas de tangerineira 'Cleópatra' (C. reshni Hort ex Tan.), em função do comprimento do embrião e do cultivo por trinta dias em diferentes concentrações de micronutrientes do meio MT (A: Etapa I e B: Etapa II). Médias seguidas da mesma letra maiúscula dentro de cada concentração e da mesma letra minúscula entre cada classe de comprimento dentro das concentrações não diferem estatisticamente, ao nível de $5 \%$ de probabilidade, pelo teste de Tukey. 


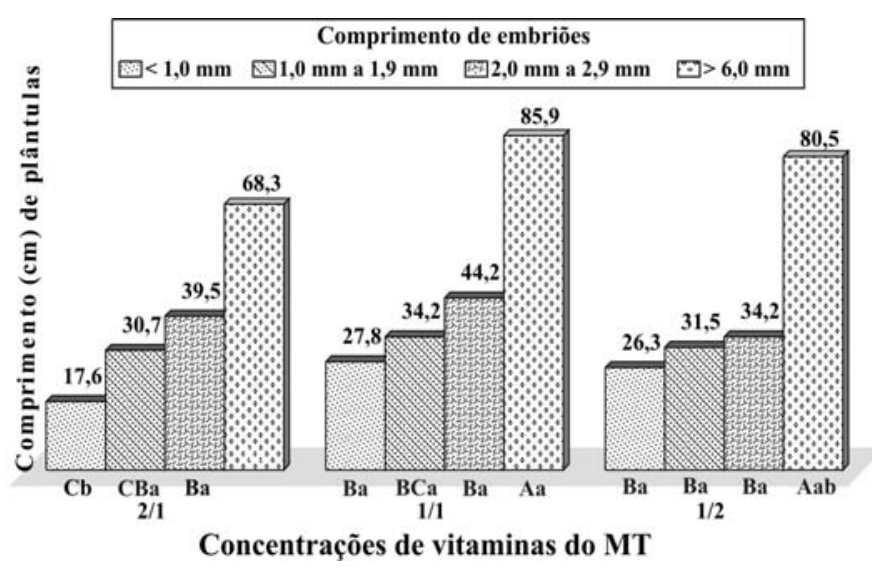

FIGURA 5 - Comprimento $(\mathrm{mm})$ de plântulas de tangerineira 'Cleópatra' (C. reshni Hort ex Tan.), em função do comprimento do embrião e do cultivo durante trinta dias, em diferentes concentrações de vitaminas do meio MT. Médias seguidas da mesma letra maiúscula dentro de cada concentração e da mesma letra minúscula entre cada classe de comprimento dentro das concentrações não diferem estatisticamente, ao nível de $5 \%$ de probabilidade, pelo teste de Tukey.

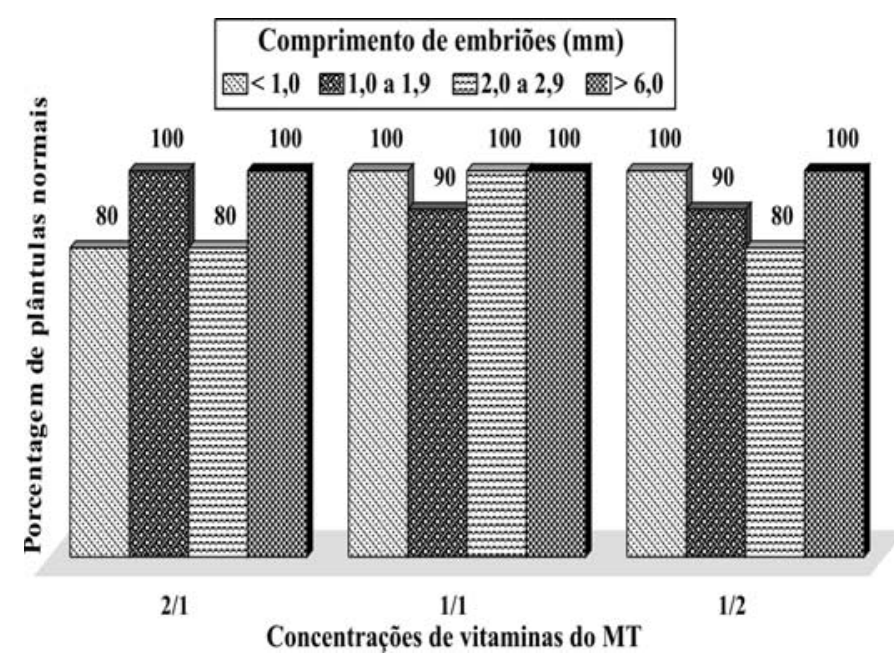

FIGURA 6 - Porcentagem de plântulas normais de tangerineira 'Cleópatra' (C. reshni Hort ex Tan.), em função do comprimento do embrião e do cultivo durante trinta dias, em diferentes concentrações de vitaminas do meio MT.

\section{CONCLUSÃO}

Os melhores resultados para germinação e desenvolvimento de plântulas normais oriundas de embriões imaturos $(<3,0 \mathrm{~mm})$ de tangerineira 'Cleópatra' foram observados quando se utilizaram as concentrações originais de micronutrientes e vitaminas, e metade da concentração de macronutrientes do meio MT.

\section{REFERÊNCIAS}

ANDRADE-RODRÍGUEZ, M.; VILLEGAS-MONTER, Á.; GUTIÉRREZ-ESPINOSAM. A.; CARRILLO-CASTAÑEDA, G.; GARCÍA-VELÁZQUEZ, A. Polyembryony and rapd markers for identification of zygotic and nucellar seedlings in Citrus. Agrociência, Chapingo, v.39, p. 371-383, 2005.

BASTIANEL, M.; SCHWARZ, S. F.; COLETAFILHO, H. D.; LIN, L. L.; MACHADO, M.; KOLLER, O. C. Identification of zygotic and nucellar tangerine seedlings (Citrus spp.) using RAPD. Genetics and Molecular Biology, Ribeirão Preto, v. 21, n. 1, Mar. 1998.

CHAGAS, E. A.; PASQUAL, M.; DUTRA, L. F.; SILVA, A. B. da; CAZETTA, J. O.; SANTOS, F. C.; CARDOSO, P. Desempenho de diferentes estádios embrionários no cultivo in vitro de embriões de 'Pêra Rio' x 'Poncã'. Revista Brasileira de Fruticultura, Jaboticabal, v. 25, n. 3, p. 523-525, dez. 2003a.

CHAGAS, E. A.; PASQUAL, M.; RAMOS, J. D.; CARDOSO, P.; CAZETTA, J. O.; FIGUEIREDO, M. A. de. Development of globular embryos from the hybridization between 'Pêra Rio' sweet orange and 'Poncã' mandarin. Revista Brasileira de Fruticultura, Jaboticabal, v. 25, n. 3, p. 483-488, 2003 b.

DOMINGUES, E.T.;TEÓFILO SOBRINHO, J.; TULMANNNETO, A.; SUGAHARA, V. Y. Poliembrionia em clones de laranja 'Pêra' e variedades assemelhadas. Bragantia, Campinas, v. 57, n. 2, p. 251-258, 1998.

GEORGE, E. F. The components of culture media. In: GEORGE, E. F. (Ed.). Plant propagation by tissue culture. London: Exegetics, 1993. p. 273-343.

HANNA, W. W.; BASHAW, E. C. Apomixis: its identification and use in plant breeding. Crop Science, Madison, v. 27, n. 6, p. 1136-1139, 1987.

HU, C. Y.; FERREIRA, A. G. Cultura de embriões. In: TORRES, A. C.; CALDAS, L. S.; BUSO, J. A. (Ed.). Cultura de tecidos e transformação genética de plantas. Brasília, DF: Embrapa-SPI: Embrapa-CNPH, 1998. v. 1, p. 371-393.

HUANG, L. C.; CHEN, W. L.; CHIU, D. S. In vitro graft-enhanced nucellar plant development in the monoembryonic Citrus grandis 
L. Journal of Horticultural Science, Ashford, v. 63, n. 4, p. 705709. 1985 .

KOLLER, O. C. Melhoramento. In: Citricultura: laranja, limão e tangerina. Porto Alegre: Rígel, 1994. 446 p.

KRIKORIAN, A. D. Medios de cultivo: generalidades, composición y preparación. In: ROCA, W. M.; MROGINSKI, L. A. (Ed.). Cultivo de tejidos en la agricultura: fundamentos y aplicaciones. Cali: CIAT, 1991. p. 41-77.

MEDEIROS, M. R. DE; MANN, R. S.; VICHIATO, M.; PASQUAL, M. Uso de marcadores isoenzimáticos na identificação de poliembriões do 'Citravo' [Citrus limonia Osb. X Poncirus trifoliata (L.) Raf. Ciência e Agrotecnologia, Lavras, v.24, n.2, p.409-416, 2000.

MURASHIGE, T.; SKOOG, F. A revised medium for rapid growth and bioassay with tobacco tissue culture. Physiology Plantarum, Copenhagen, v. 15, p. 473-497, 1962.

MURASHIGE, T.; TUCKER, D. P. H. Growth factor requirement of citrus tissue culture. In: INTERNATIONAL CITRUS SYMPOSIUM, 1., 1969, Riverside. Proceedings... Riverside. University of California, 1969. v. 3, p. 1155-1161.

PASQUAL, M.; ALVES, G. P.; DUTRA, L. F.; FINOTTI, D. R.; CHAGAS, E. A. Cultivo in vitro de embriões imaturos de tangerineira 'Poncã': concentrações do meio MS e da sacarose. Revista Ceres, Viçosa, MG, v. 49, n. 282, p. 181-189, 2002.
PASSOS, I. R. da S.; POMMER, C. V.; HAAS, M. G.; PIRES, E. J. P.; TERRA, M. M.; FALCO, M. C. Obtenção de híbridos entre cultivares apirenas de videira, utilizando a técnica de resgate de embriões. Revista Brasileira de Fruticultura, Cruz das Almas, BA, v. 14, n. 2, p. 215-220, 1992.

RIBEIRO, V. G.; PASQUAL, M.; RAMOS, J. D.; VICHIATO, M.; SANÁBIO, D. Cultivo in vitro de embriões de laranja 'Pêra': concentrações do meio MS e sacarose. Ciência. e Agrotecnologia, Lavras, v. 22, n. 4, p. 429-434, 1998.

RIBEIRO, V. G. Posicionamento de embriões zigóticos e nucelares em sementes de citros e ajuste do meio "MS" para o resgate de embriões in vitro. 1997. 57 f. Dissertação (Mestrado em Fitotecnia) - Universidade Federal de Lavras, Lavras, 1997.

SOOST, R. K. ROOSE, M. L. Citrus. In: JANICK, J.; MOORE, J. N. (Ed.). Fruit breeding: tree and tropical fruits. New York: John Wiley \& Sons, 1996. v. 1, p. 257-322.

VÁSQUEZ ARAÚJO, J. E. Identificação de embriões zigóticos em sementes poliembriônicas de citros (Citrus sp.) mediante características morfológicas. 1991. 74 f. Dissertação (Mestrado em Agronomia) - Escola de Agronomia, Universidade Federal da Bahia, Cruz das Almas, 1991.

VILORIA, Z.; GROSSER, J. W.; BRACHO, B. Immature embryo rescue, culture and seedling development of acid citrus fruit derived from interploid hybridization. Plant Cell, Tissue and Organ Culture, Hague, v. 82, p. 159-167, 2005. 